\title{
Time trends of Helicobacter pylori prevalence in Itajaí - SC: a retrospective study of 25 years based on endoscopic database
}

\author{
Fangio FERRARI' ${ }^{1}$, Elisa Cantú Germano DUTRA ${ }^{1}$, Henrieli Correia ZANARDI ${ }^{1}$, Bruno Lorenzo SCOLARO ${ }^{1}$ and \\ Odemari Miranda FERRARI ${ }^{2}$
}

Received 31/8/2018 Accepted 25/2/2019

\begin{abstract}
Background - The bacterium Helicobacter pylori is strongly associated with the development of gastric adenocarcinoma. Currently, the prevalence in developed countries is $40 \%$, but this value increases considerably in developing countries, which can reach rates bigger than $90 \%$. Objective - The objective of this study was to determine the mean and annual prevalence of Helicobacter pylori infection in patients from Itajaí during the period from July 1992 to April 2016, as well as the gender and age groups most affected. Methods - After consent of the clinical director of the Gastroclinica Itajaí and confidentiality commitment about the research, the database of the Endoscopy Service of the clinic was evaluated. All the patients who underwent their first upper digestive endoscopy with urease test and/or histological analysis were included. The data were submitted to statistical analysis of prevalence by gender, age group and years of study, with subsequent correction through the confidence interval. Results - The mean prevalence of Helicobacter pylori infection thru all years of study was $50.07 \%$. With the calculation of the annual prevalences, it was evident the gradual reduction of infection in the population of Itajaí, that was $81.3 \%$ in 1992, declining to 33\% in the year of 2016 . When classifying the prevalence of infection by gender, it was higher in males (53.59\%), and gender distribution by age group showed no statistically significant difference among genders between the ages of 40 and 80 years. In relation to the age group, the highest prevalence was in the group between 40 and 49 years. Conclusion - Although this study is retrospective and based on endoscopic database analysis, without access to clinical data of patients such as prior use of proton pump inhibitor and antibiotics to endoscopy, its results are important because they may reflect the current panorama of Helicobacter pylori infection in the city under study, where it has been presenting a gradual reduction of prevalence over the years, with current rates similar to that of developed countries (33\%). Future studies are needed to confirm our data.
\end{abstract}

HEADINGS - Helicobacter infections. Prevalence. Epidemiology.

\section{INTRODUCTION}

The bacterium Helicobacter pylori is a gram-negative bacillus that was discovered in 1983, only about a century after the onset of pathological stomach analysis. It presents as main reservoir the human stomach, colonizing its epithelium. Several studies have already demonstrated its relationship with gastrointestinal diseases, and the presence of the bacterium is a risk factor for chronic and atrophic gastritis, peptic ulcer disease, intestinal metaplasia, gastric adenocarcinoma and mucosal lymphoid tissue lymphoma (MALT) $^{(1,2,3)}$

In 1994, the International Agency for Research on Cancer (IARC) classified Helicobacter pylori as a group I carcinogen with proven carcinogenic activity for low-grade gastric B-cell lymphoma and for distal adenocarcinoma. At the time, it was estimated that $60 \%$ of gastric cancers and $5.5 \%$ of the total number of cancer cases registered worldwide would be caused by this bacterium ${ }^{(2)}$.

In addition, its study is important due to the high prevalence rate worldwide, which affects around $50 \%$ of the population. Developing countries achieve rates of up to $90 \%$, while in developed countries rates are generally below $40 \%$. Long-term infection significantly increases the risk of developing site-specific and even extra-digestive diseases, such as idiopathic thrombocytopenic purpura and idiopathic iron deficiency anemia ${ }^{(4,5,6)}$.

Since little is known about the epidemiological trends of this infection in the city of Itajaí - Santa Catarina (SC) - Brazil, besides the importance of the infection of this microorganism and the scale of its consequences, it is essential to carry out epidemiological studies in order to determine the current panorama of this infection and associated diseases.

Thus, the objective of this study was to determine the prevalence of Helicobacter pylori infection in patients submitted to upper gastrointestinal endoscopy at Gastroclínica Itajaí during the period from July 1992 to March 2016, as well as to analyze the annual prevalence of Helicobacter pylori infection in the period studied and determine the age and gender in which there is a higher prevalence of infection. 


\section{METHODS}

\section{Study population and data collection}

This retrospective study was carried out at Gastroclínica Itajaí, a referral center in Santa Catarina - Brazil which attends patients from private and public health system. Patient informed consent forms were waived since this is a retrospective study based in archived database.

The research protocol was approved by the Research Ethics Committee of the Universidade do Vale do Itajaí (UNIVALI), under registration number 54191016.2.0000.0120.

After consent of the clinical director of the Gastroclinica Itajai and confidentiality commitment about the research, the database of the Endoscopy Service of the clinic was evaluated. The database had reports of 41174 upper endoscopic exams performed between June 1992 to April 2016.

\section{Inclusion criteria}

The study included the data of the patients first upper endoscopy at the clinic, with biopsies of the antrum and gastric body for urease test and/or histological analysis, independent of gender, age or ethnicity during the period of June 1992 to April 2016.

\section{Exclusion criteria}

Patients without urease test and/or histology results.

Subsequent endoscopies or pathology control endoscopies of the same patient were excluded.

\section{Data analysis}

Patients whose urease test acquired pink-violet staining were determined positive for Helicobacter pylori infection in the time determined by the kit used (Uretest ${ }^{\circledR}$, Renylab Ltda., Minas Gerais, Brazil), at room temperature.

In relation to the histological analysis, the slides considered positive were the ones that stained by hematoxylin-eosin and later by Giemsa evidenced the presence of Helicobacter pylori.

Data were analyzed with the 15.25 version of Microsoft Excel $2016^{\circledR}$ software and the whole period prevalence and annual prevalence were calculated stratified both by sex and age group. The prevalence was expressed as the percentage of patients with positive urease test and/or gastric biopsy among all the exams performed. The age group comprised the following groups: younger than 20 years; between $20-29 ; 30-39 ; 40-49 ; 50-59 ; 60-69 ; 70-79$ and over 80 years old. After the determination of the prevalence, the values found were corrected with a confidence interval for a ratio with probability of error $P=0.05$, which corresponds to a reliability of the data of $95 \%$.

\section{Ethical considerations}

Because it is a retrospective study of database analysis, the risks involved disclosure of confidential data, as well as the use of the sample for further research without authorization. The confidentiality and privacy of the data was ensured, ensuring the non-use of the information in other works. There was no access to medical records, since the data were imported from a previously existing database in the endoscopy sector of Gastroclínica Itajaí.

\section{RESULTS}

Of the 41,174 endoscopies present in the database, 20,398 exams were selected after applying the inclusion criteria, of which 11,960 $(58.6 \%)$ were female and $8,438(41.4 \%)$ were male. The mean age was 40.96 years, ranging from 9 to 96 years. When taking into consideration the method of diagnosis of Helicobacter pylori, $924(4.53 \%)$ patients were evaluated by histology and 19,474 (95.47\%) by urease test.

The total prevalence of Helicobacter pylori infection in the period studied (June 1992 to April 2016) was 50.07\%, corresponding to 10,213 patients.

When classifying the prevalence of the infection by gender, we noticed that it was higher in males, corresponding to $53.59 \%$ of the sample of male patients positive for the infection. Analyzing the distribution of genders by age group of patients with Helicobacter pylori infection, we observed a higher prevalence in males in all age groups, with the exception of patients in the 70-79 age group, where the proportion of female patients with infection was higher (FIGURE 1, TABLE 1). However, after the confidence interval was calculated, it was demonstrated that there is no statistically significant difference between genders between the ages of 40 to 80 years.

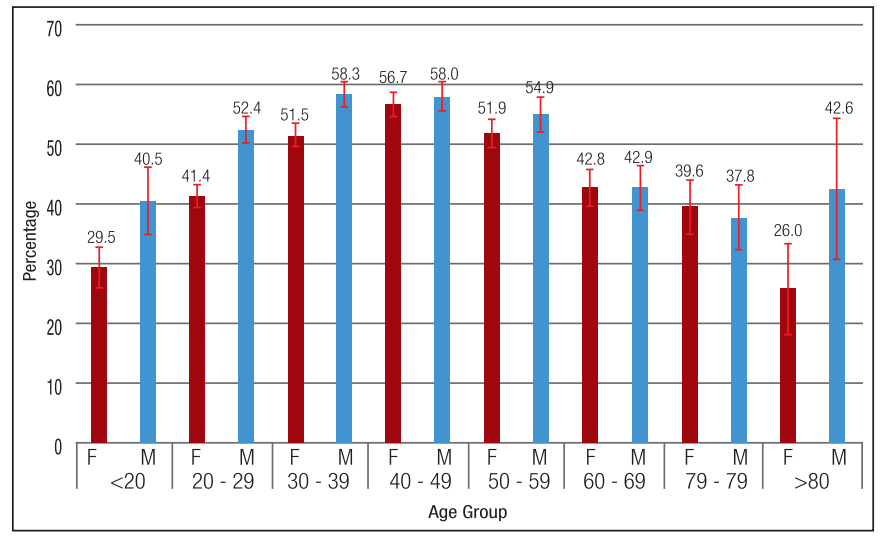

FIGURE 1. Percentage distribution by gender and age group of patients positive for Helicobacter pylori infection in Itajaí during all period of study (1992-2016). F: female; M: male.

TABLE 1. Distribution of Helicobacter pylori infection according to gender by age group (whole period).

\begin{tabular}{lcccccccc}
\hline Age group (years) & $<20$ years & $20-29$ & $30-39$ & $40-49$ & $50-59$ & $60-69$ & $70-79$ & $>80$ \\
\hline Total $H p .+(\mathrm{n})$ & & & & & & & \\
Female & 729 & 2600 & 2709 & 2444 & 1832 & 1050 & 472 & 123 \\
Male & 296 & 1852 & 2206 & 1780 & 1182 & 739 & 315 & 68 \\
Hp.+ (\%) with CI $P=0.05$ & & & & & & & \\
Female & $29.5 \%$ & $41.4 \%$ & $51.5 \%$ & $56.7 \%$ & $51.9 \%(49.6-$ & $42.8 \%$ & $39.6 \%$ & $26.0 \%$ \\
& $(26.2-32.8)$ & $(39.5-43.3)$ & $(49.6-53.4)$ & $(54.7-58.7)$ & $54.1)$ & $(39.8-45.8)$ & $(35.2-44.0)$ & $(18.3-33.8)$ \\
Male & $40.5 \%$ & $52.4 \%$ & $58.3 \%$ & $58.0 \%$ & $54.9 \%$ & $42.9 \%$ & $37.8 \%$ & $42.6 \%$ \\
& $(34.9-46.1)$ & $(50.1-54.7)$ & $(56.2-60.4)$ & $(55.7-60.3)$ & $(52.1-57.7)$ & $(39.3-46.5)$ & $(32.4-43.1)$ & $(30.9-54.4)$ \\
\hline
\end{tabular}

Hp. $+=$ Helicobacter pylori positive; $\mathrm{CI}=$ Confidence interval 
When evaluating the distribution of patients positive for the infection by age group, we found that the prevalence is higher between 40 and 49 years, with a total of 2418 patients $(57.2 \%)$. This value did not present a statistically significant difference in relation to the adjacent decade (30-39 years), which does not occur when compared to others age groups. In the group of patients younger than 20 years, the prevalence was lower than the group of adults, with a prevalence of $32.7 \%$ (FIGURE 2, TABLE 2).

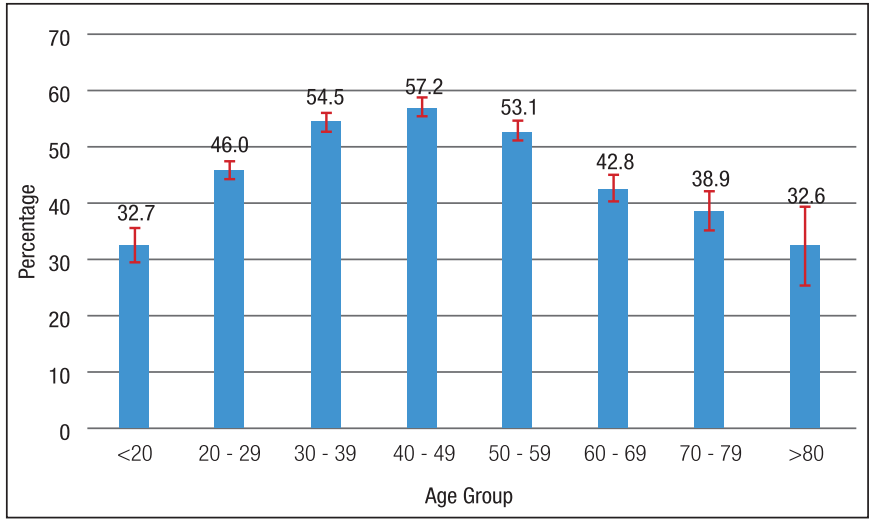

FIGURE 2. Percentage distribution by age group of patients positive for Helicobacter pylori infection in Itajaí during all period of study (1992-2016).
After these analyzes, we calculated the prevalence for each year of study (TABLE 3), in order to obtain a behavior pattern curve of Helicobacter pylori infection in Itajaí. For greater reliability of the results, we excluded the values referring to the year 1992 because the sample was very reduced when compared to the other years. The data show that initially the pattern of Helicobacter pylori infection was similar to developing regions, with a rate of $81.3 \%$ in 1993. Over time, the behavior of this infection became similar to developed regions, with the value of 33\% in 2016 (FIGURE 3).

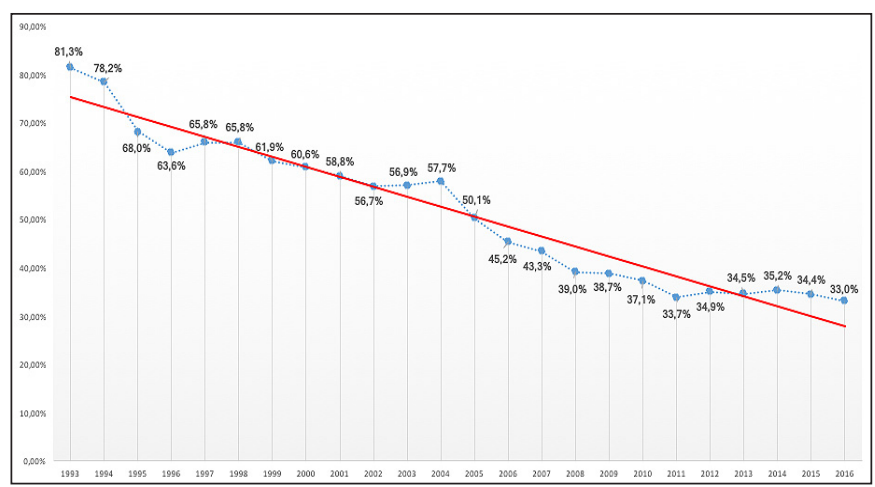

FIGURE 3. Behavior pattern curve of Helicobacter pylori infection in Itajaí from the annual prevalence rates.

TABLE 2. Distribution of Helicobacter pylori infection by age group (whole period).

\begin{tabular}{lcccccccc}
\hline Age group (years) & $<20$ years & $20-29$ & $30-39$ & $40-49$ & $50-59$ & $60-69$ & $70-79$ & $>80$ \\
\hline Total $H p .+(\mathrm{n})$ & 1025 & 4452 & 4915 & 4224 & 3014 & 1789 & 787 & 191 \\
\multirow{2}{*}{$H p .+(\%)$ with CI $P=0.05$} & $32.7 \%$ & $46.0 \%$ & $54.5 \%$ & $57.2 \%$ & $53.1 \%$ & $42.8 \%$ & $38.9 \%$ & $32.6 \%$ \\
& $(29.8-35.6)$ & $(44.5-47.4)$ & $(53.2-55.9)$ & $(55.8-58.7)$ & $(51.3-54.8)$ & $(40.5-45.1)$ & $(35.5-42.3)$ & $(25.9-39.2)$ \\
\hline
\end{tabular}

Hp. $+=$ Helicobacter pylori positive; CI: confidence interval.

TABLE 3. Total sample per year and annual prevalence rate of Helicobacter pylori infection by gender.

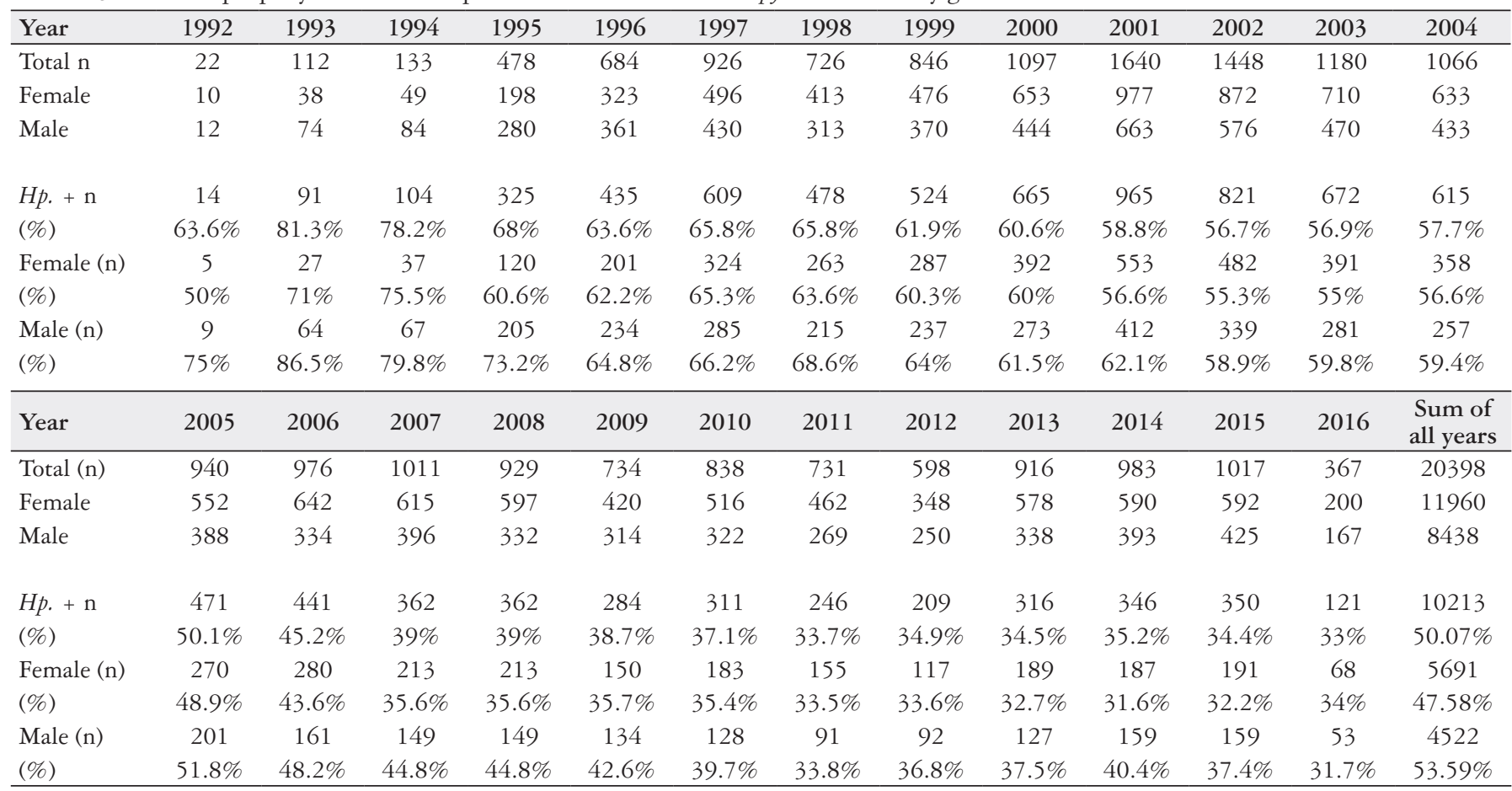

Hp. + = Helicobacter pylori positive. 


\section{DISCUSSION}

Possible biases should be taken into account in this research, especially since it is a retrospective study of an endoscopic database, without access to the clinical data of the patients studied. Factors such as previous endoscopic examination followed by eradication therapy of Helicobacter pylori in other clinics before endoscopy in the service under study, lack of prior antibiotic use data within 30 days prior to examination, as well as use of proton pump inhibitors, may have influenced the results found.

In order to minimize these biases, we adopted as inclusion criteria only the data of the first endoscopy performed at the clinic, thus excluding possible endoscopic exams for eradication control of the bacteria, and also patients who performed multiple endoscopies over the years, generating repetitive data.

The prevalence of Helicobacter pylori infection found in this study is similar to those of Ireland (43.0\%), Spain (54.9\%), South Korea $(54.0 \%)$ and Taiwan $(53.9 \%)$ found on a recently published systematic review and meta-analysis. Most developing countries have higher rates, such as $92 \%$ in Bangladesh, $63.5 \%$ in India, $69 \%$ in Colombia and $74.6 \%$ in Chile. Developed countries, such as Australia (24.6\%), Denmark (22.1\%), Netherlands (35.5\%), Sweden (26.2\%), Germany (35.3\%), United States (35.6\%), United Kingdom (35.5\%) and Switzerland (18.9\%) present lower values than the one found in this study in Itajai ${ }^{(7,8,9)}$.

Compared to Brazilian values, this study showed a lower prevalence of Helicobacter pylori infection in Itajaí $(50 \%)$ than northern region results (with $80 \%$ of the population affected), Southeast (cities of São Paulo with $65 \%$ and Belo Horizonte with $62.1 \%$ ) and Northeast (Salvador with $68.2 \%$ ). When compared to the estimated prevalence of Helicobacter pylori infection in Brazil $(71.2 \%)$ for the year of 2015 based on United Nations Revision of World Population Prospects, the results of this study were pretty lower for that year $(34.4 \%)$. Such findings may reflect the greater socioeconomic development of the Southern region of Brazil compared to other regions of the country, as well as better quality of food and easy access to upper digestive endoscopy. As outlined in the literature, Helicobacter pylori infection is higher in poorer populations. Improving the city's basic sanitation and hygiene conditions reduces the prevalence rate of the infection. In addition, the study was carried out in a private clinic, in which, until the year 2010, performed exams in patients from the public health system, reflecting in the socioenvironmental conditions of the analyzed sample $\mathrm{e}^{(9,10,11,12,13)}$.

These contrasts between different regions in the same country are also found worldwide, where the prevalence of Helicobacter pylori infection in the Alaskan indigenous population $(74.8 \%)$ is significantly higher than that of the general population of the United States $(35.6 \%)^{(9)}$.

The prevalence data for under 20-year-old in the city of Itajai $(32.7 \%)$ resemble a study of the same methodology performed in Belo Horizonte, which found a prevalence of approximately $35 \%$ in this age group. The same study showed higher values in rural and poor regions, such as $77.5 \%$ in Mato Grosso do Sul and $51 \%$ in Porto Velho. As a counterpoint, regions with high socioeconomic status have lower values, such as $24.86 \%$ in the city of Porto Alegre ${ }^{(14)}$.

Other factors that may indirect reflect this gradual reduction in Helicobacter pylori infection would be the use of antibiotics in the medical environment for purposes other than the eradication of Helicobacter pylori, and also the use without prescription. In addition, it is recommended to suspend the use of proton pump inhibitor (PPI) from 7 to 14 days before endoscopy so that the results of both histopathological exams and urease test reach their maximum sensitivity. Thus, as the use of these drugs is frequent in the Brazilian population, this may have been a factor that corroborated for this low prevalence, once it would have resulted in false negative data because these patients were not excluded from the inclusion criteria and most of the patients in this study were evaluated by urease test.

We should also take into account that with the significant increase in the offer of treatment of Helicobacter pylori in the population and the absence of noninvasive diagnostic tests for infection cure in the population studied, endoscopy performed for this purpose may have been responsible for the progressive reduction of the prevalence of Helicobacter pylori over the years, since many of the patients could have eradicated the bacterium in other services and have only undergone a eradication control endoscopy in the service under study. Corroborating with this hypothesis, data from the pharmaceutical industry regarding the sale of Helicobacter pylori eradication kits during the last five years showed an increase of $12.25 \%$ on the region studied.

Regarding the distribution of genders by age group, the result found reinforces data already existing in the current literature, which does not observe significant statistical difference between genders $^{(11,14,15)}$.

\section{CONCLUSION}

Although this study is retrospective and based on endoscopic database analysis, without access to clinical data of patients such as prior use of PPIs and antibiotics to endoscopy, its results are important because they may reflect the current panorama of Helicobacter pylori infection in the city under study. However, we must take into account that most of the studied population possibly refers to dyspeptic patients who underwent endoscopy in a private service, which may underestimate the actual local prevalence of Helicobacter pylori infection since many infected patients may be asymptomatic, and yet not forget that many other patients without access to health care facilities may not have been studied.

From this research, it was possible to observe that the average prevalence of Helicobacter pylori infection over the years 1992 to 2016 was $50.07 \%$.

However, from the analysis of prevalence by year, it was possible to verify that the infection in the last years presented a gradual reduction in the population of Itajaí, with a rate of $81.3 \%$ in 1993 , reaching 33\% in 2016 .

Among the patients with Helicobacter pylori infection, the majority are male, but when considering the confidence interval, it is observed that there is no significant statistical difference between genders from 40 to 80 years.

In relation to the age group, the highest prevalence was in the group between 40 and 49 years. However, there is no statistically significant difference compared to the adjacent decade (30-39 years).

Future studies are needed to confirm our estimates and also prospective studies evaluating the possible complications associated with Helicobacter pylori infection, especially the pre-neoplastic and neoplastic lesions. 


\section{ACKNOWLEDGEMENTS}

The authors are grateful to Gastroclínica Itajaí for the collaboration and authorization to use their data for the execution of this research.

\section{Authors' contribution}

Ferrari F: data collection, research execution, statistical analysis, text writing and review. Dutra ECG: data collection, research execution, statistical analysis, text writing. Zanardi HC: data collection, research execution, statistical analysis, text writing. Scolaro BL: text writing and review. Ferrari OM: data collection, research execution.

\section{Orcid}

Fangio Ferrari. Orcid: 0000-0003-4395-7374.

Elisa Cantú Germano Dutra. Orcid: 0000-0002-9726-5712.

Henrieli Correia Zanardi. Orcid: 0000-0001-6254-3551.

Bruno Lorenzo Scolaro. Orcid: 0000-0001-6277-7075.

Odemari Miranda Ferrari. Orcid: 0000-0003-4430-2396.

Ferrari F, Dutra ECG, Zanardi HC, Scolaro BL, Ferrari OM. Tendências temporais da prevalência de Helicobacter pylori em Itajaí - SC: um estudo retrospectivo de 25 anos baseado em banco de dados endoscópicos. Arq Gastroenterol. 2019;56(1):10-4.

RESUMO - Contexto - A bactéria Helicobacter pylori associa-se fortemente ao desenvolvimento do adenocarcinoma gástrico. Atualmente, a prevalência em países desenvolvidos é de $40 \%$, porém esse valor cresce consideravelmente em países em desenvolvimento, que chegam a alcançar taxas de até $90 \%$. Objetivo - O objetivo desta pesquisa foi determinar a prevalência média e anual da infecção por Helicobacter pylori nos pacientes de Itajaí durante o período de julho de 1992 a abril de 2016, assim como o sexo e as faixas etárias mais acometidas. Métodos - Após consentimento do diretor técnico da Gastroclínica Itajaí e comprometimento de sigilo em relação à pesquisa, foi avaliada a base de dados do Serviço de Endoscopia da clínica. Foram selecionados todos os pacientes que realizaram pela primeira vez o exame de endoscopia digestiva alta com teste da urease e/ou análise histológica. Os dados obtidos foram submetidos à análise estatística de prevalência por sexo, faixa etária e anos do estudo, com posterior correção dos dados através do intervalo de confiança. Resultados - A prevalência média da infecção por Helicobacter pylori em todos os anos de estudo foi de 50,07\%. Com o cálculo das prevalências anuais, ficou evidente a redução gradual da infecção na população de Itajaí, que era de 81,3\% em 1992, passando a 33\% no ano de 2016. Ao classificar a prevalência da infecção por gênero, foi maior no sexo masculino $(53,59 \%)$ e a distribuição dos gêneros por faixa etária não mostrou diferença estatisticamente significativa entre os sexos entre as idades de 40 a 80 anos. Em relação à faixa etária, a maior prevalência foi no grupo entre 40 e 49 anos. Conclusão - Embora este estudo seja retrospectivo e baseado em análise de banco de dados de endoscopias digestivas, sem acesso a dados clínicos de pacientes como uso prévio de nibidor de bomba de próton e antibióticos à endoscopia, seus resultados são importantes, pois podem refletir o panorama atual da infecção por Helicobacter pylori no município em estudo, que vem apresentando uma redução gradual da prevalência ao longo dos anos, com taxas atuais semelhantes às dos países desenvolvidos (33\%). Estudos futuros são necessários para confirmar nossos dados.

DESCRITORES - Infecções por Helicobacter. Epidemiologia.

\section{REFERENCES}

1. Vinagre IDF, Queiroz AL de, Silva Júnior MR da, Vinagre RMDF, Martins LC Helicobacter pylori infection in patients with diferente gastrointestinal diseases from Northern Brazil. Arq Gastroenterol. 2015;52:266-71.

2. Whalen MB, Massidda O. Helicobacter pylori: enemy, commensal or, sometimes, friend? J Infect Dev Ctries. 2015;9:674.

3. Nardone G, Compare D. The human gastric microbiota: Is it time to rethink the pathogenesis of stomach diseases? United Eur Gastroenterol J. 2015;3:255-60.

4. Ermis F, Senocak Tasci E. Current Helicobacter pylori treatment in 2014. World J Methodol. 2015;5:101-7.

5. Graham DY. Helicobacter pylori: Molecular and cellular biology. Gastroenterology. 2001;121:740-1. DOI: https://doi.org/10.1016/S0016-5085(01)70143-6.

6. Vale FF, Vítor JM. Transmission pathway of Helicobacter pylori: Does food play a role in rural and urban areas? Int J Food Microbiol. 2010;138:1-12.

7. Khalifa MM, Sharaf RR, Aziz RK. Helicobacter pylori: a poor man's gut pathogen? Gut Pathog. 2010;2:2

8. Peleteiro B, Bastos A, Ferro A, Lunet N. Prevalence of Helicobacter pylori Infection Worldwide: A Systematic Review of Studies with National Coverage. Dig Dis Sci. 2014;59:1698-709.

9. Hooi JKY, Lai WY, Ng WK, Suen MMY, Underwood FE, Tanyingoh D, et al. Global Prevalence of Helicobacter pylori Infection: Systematic Review and Meta-Analysis. Gastroenterology. 2017;153:420-9.
10. Zaterka S, Eisig JN, Chinzon D, Rothstein W. Factors Related to Helicobacter pylori Prevalence in an Adult Population in Brazil. Helicobacter. 2007; 12:82-8.

11. Vergueiro CSV, Cordiolli R, Martucci D, Peres V, Kiyamu AR, Ribeiro K de CB, et al. Seroprevalence and epidemiological aspects of Helicobacter pylori infection in bone marrow donors in São Paulo. Rev Bras Epidemiol. 2008;11:196-203.

12. Santos IS, Boccio J, Santos AS, Valle NCJ, Halal CS, Bachilli MC, Lopes RD Prevalence of Helicobacter pylori infection and associated factors among adults in Southern Brazil: a population-based cross-sectional study. BMC Public Health. 2005 Dec 10;5:118.

13. Frugis S, Czeczko NG, Malafaia O, Parada AA, Poletti PB, Secchi TF, et al Prevalence of Helicobacter pylori ten years ago compared to the current prevalence in patients undergoing upper endoscopy. [Article in Portuguese]. ABCD Arq Bras Cir Dig (São Paulo). 2016;29:151-4

14. Muller LB, Fagundes RB, Moraes CC de, Rampazzo A. Prevalence of Helicobacter pylori infection and gastric cancer precursor lesions in patients with dyspepsia. [Article in Portuguese]. Arq Gastroenterol. 2007;44:93-8.

15. Oliveira JG de, Ferreira CHT, Camerin ACS, Rota CA, Meurer L, Silveira TR da. Prevalence of infection with Cag-A-Positive Helicobacter pylori strains among children and adolescents in Southern Brazil. Arq Gastroenterol. 2014;51:180-5.

\section{(c)) BY-NC}

